Am. J. Trop. Med. Hyg., 28(2), 1979, pp. 351-363

Copyright (C) 1979 by The American Society of Tropical Medicine and Hygiene

\title{
GEOGRAPHIC DISTRIBUTION OF ARBOVIRUS ANTIBODIES IN INDIGENOUS HUMAN POPULATIONS IN THE INDO-AUSTRALIAN ARCHIPELAGO*
}

\author{
MASATSUGU KANAMITSU, $\dagger$ KOKI TANIGUCHI, SHOZO URASAWA, \\ TAKAYUKI OGATA, YOSHITO WADA, YOSHITAKE WADA, AND J. SULIANTI SAROSO \\ Department of Hygiene and Epidemiology, Sapporo Medical College, Sapporo, Japan, \\ Department of Virology and Rickettsiology, National Institute of Health, Tokyo, Japan, \\ Department of Medical Zoology, Faculty of Medicine, Nagasaki University, Nagasaki, Japan, \\ Department of Parasitology, Tokyo Women's Medical College, Tokyo, Japan, and \\ National Institute of Health Research and Development, Ministry of Health, Jakarta, Indonesia
}

Abstract. Sera from lifetime residents in 16 localities of the Indo-Australian archipelago and adjacent areas were tested for hemagglutination-inhibition antibody against four alphaviruses (Sindbis, Getah, chikungunya, and Ross River) and for neutralizing antibody against six flaviviruses (dengue 2 and 3, Japanese encephalitis, Murray Valley encephalitis, Kunjin, and Edge Hill). Mosquito collections were carried out in some of the localities to study vector relationships to distribution of the arbovirus antibodies. Antibodies specific to Sindbis and Getah viruses were rare except in north Australia. Chikungunya virus-specific antibody was highly prevalent in localities of the Oriental zoogeographic region and Wallacea, rare in west New Guinea, and absent in north Australia. Age distribution of chikungunya antibody suggested that the antibody last occurred in most Indonesian localities about 30 years ago. Ross River virus-specific antibody was confined to localities of the Australian zoogeographic region. Antibodies reacting to dengue 2 and 3 viruses occurred in high frequency in the entire area of the archipelago. Antibodies specific to Murray Valley encephalitis and Kunjin viruses were also widespread although at a very low frequency. Japanese encephalitis virus-specific antibody was highly prevalent in areas west of Wallace's Line while it was absent in areas east of the line with the exception of Lombok. Antibody to Edge Hill virus was rare and confined to the Australian zoogeographic region. The distribution of arthropod vectors, vertebrate hosts, and of arboviruses are discussed in relation to zoogeographic divisions.

The number of viruses known or suspected of being arthropod-borne is now in excess of $300 .^{1}$ A given arbovirus is usually confined to one or two zoogeographic regions although antigenically related arboviruses may have a wider distribution. ${ }^{2.3}$ It is highly probable that both the vertebrate hosts and arthropod vectors play a role in the evolution and distribution of these viruses. ${ }^{4-7}$

Accepted 1 July 1978.

* This study was reported in part at the conference on viral diseases which was held by the Japan-U.S. Cooperative Medical Science Program in Washington, D.C., in 1973, and also at the 21 st general meeting of the Society of Japanese Virologists in Tokyo in the same year. The study was supported in part by a grant in 1974 from the Ministry of Education, Japan.

Address reprint requests to: Dr. Masatsugu Kanamitsu, c/o JICA, Embassy of Japan, 24 Jalan Thamrin, Jakarta, Indonesia.

$\dagger$ Professor Emeritus.
Although a number of studies on arbovirus distribution in Southeast Asia and Australasia have been reported, ${ }^{8-13}$ little is known about their distribution and prevalence in the Indo-Australian archipelago where the fauna of the Oriental and Australian regions meet. ${ }^{14-17}$ Therefore, the Indonesian islands provide an excellent area for the ecologic study of arboviruses.

Although isolation of virus from man and animals is an ideal way to determine arbovirus distribution, this was not possible due to lack of laboratory and logistical support in the area. Therefore, we attempted to study arbovirus distribution by serologic survey of indigenous human populations. Results of our preliminary survey demonstrated distinct regional differences in the prevalence of some arbovirus antibodies. ${ }^{18}$ In the present study, we extended the serologic survey to include four alpha- and six flaviviruses in sera from the archipelago and adjacent areas. Collection of mosquitoes was also carried out at 


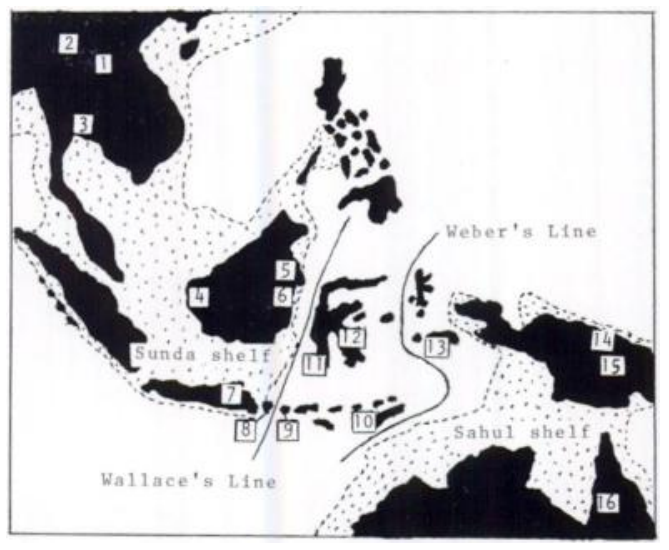

FIGURE 1. Zoogeographic divisions of the IndoAustralian archipelago, and localities at which human serum samples were collected. 1, Vientiane; 2, Chiang Mai ; 3, Bangkok; 4, Pontianak; 5, Samarinda; 6, Balikpapan; 7, Surabaya ; 8, Bali; 9, Lombok; 10, Kupang; 11, Ujung Pandang; 12, Pomalaa; 13, Ambon; 14, Jayapura; 15, Pit River; 16, Queensland. The spotted areas indicate $200 \mathrm{~m}$ depth of the sea (continental shelves). ${ }^{14}$

limited localities to study vector relationships to virus distribution.

\section{MATERIALS AND METHODS}

Sera

Human serum samples were collected at 16 localities between Laos and north Australia, with particular emphasis on the Indo-Australian achipelago (Fig. 1). Blood donors were carefully questioned about their life histories since birth, and blood samples were taken only from lifetime residents in the respective localities. Thus, about 2,500 serum samples were obtained since 1972 . The Laosian sera were collected through cooperation of Dr. S. Yamaguchi, Tha Ngone Medical Center, Vientiane. Siamese sera were given by Dr. P. Chiowanich, Chiang Mai University School of Medicine and Dr. P. Tuchinda, Department of Medical Science, Ministry of Health, Thailand. Sera of New Guinean aborigines in Pit River were supplied by Dr. M. J. Simon, WHO Immunology Research and Training Center, Singapore, and those of natives in north Australia were provided by Dr. R. L. Doherty, Queensland Institute of Medical Science, Brisbane. All sera were heatinactivated at $56^{\circ} \mathrm{C}$ for $30 \mathrm{~min}$ and stored at $-75^{\circ} \mathrm{C}$ until use.

\section{Viruses}

Four alphaviruses, Sindbis (SIN), Getah (GET), chikungunya (CHIK), and Ross River (RR), and six flaviviruses, dengue (D-2 and D-3), Japanese encephalitis (JE), Murray Valley encephalitis (MVE), Kunjin (KUN), and Edge Hill (EH), were used in these studies. The Egypt Ar339 strain of SIN, AMM 2021 strain of GET, JaGAr01 strain of JE, Trinidad strain of D-2, and Phil H87 strain of D-3 viruses were supplied by Dr. A. Oya, Department of Virology and Rickettsiology, National Institute of Health, Tokyo. The MVE virus strain was from the 406th Medical General Laboratory of U.S. Army, Japan. The African strain of CHIK was provided by Dr. A. Igarashi, Institute of Microbial Diseases, Osaka University, and T-48 strain of RR was provided by Dr. R. E. Shope, Yale Arbovirus Research Unit, New Haven, U.S.A. The MRM 16 strain of KUN and C281 strain of EH were given by Dr. R. L. Doherty.

\section{Antibody Examination}

Antibodies to the alphaviruses were tested by the hemagglutination-inhibition (HI) method. Antigens were prepared from virus-infected BHK21 cell cultures according to the method of Mussgay and Rott, ${ }^{19}$ except for SIN virus hemagglutinins which were prepared from virus-infected suckling mouse brains according to the method of Clarke and Casals. ${ }^{20}$ Survey sera were screened at a dilution of $1: 10$ using eight units of antigen, and positive sera were tested further at higher dilutions.

Antibodies to the flaviviruses were tested by the neutralization method using a microplate. The method of De Madrid and Porterfield ${ }^{21}$ was modified for mass examination of neutralizing antibody using minimal amounts of serum as follows: ${ }^{22} 0.025 \mathrm{ml}$ of PS cell suspension, adjusted to contain 2.0 to $2.5 \times 10^{5}$ cells per ml, were poured into each well of a microplate. Confluent cell sheets were formed after incubation at $37^{\circ} \mathrm{C}$ for 24 hours. Twofold serial dilutions, beginning from $1: 4,0.025 \mathrm{ml}$ each, of serum were mixed with same volume of virus (32-100 $\left.\mathrm{TCID}_{50}\right)$. The serum-virus mixtures were transferred to the microplate with cell sheets after replacement of growth medium with $0.025 \mathrm{ml}$ of Earle's MEM supplemented with $10 \%$ triptose phosphate broth, $8 \%$ heat-inactivated bovine 
serum, $2 \%$ newborn calf serum and antibiotics. The plate was kept at $37^{\circ} \mathrm{C}$ for an additional hour, then $0.075 \mathrm{ml}$ of overlay medium consisting of $1.5 \%$ carboxy-methyl-cellulose (CMC) in Eagle's MEM was poured into the wells. After incubation at $37^{\circ} \mathrm{C}$ for 4-6 days, the overlay medium was decanted, the cell sheets were fixed with Zenker's solution and stained with $0.1 \%$ trypan blue. Neutralization tests with D-2 virus were carried out in the same manner using BHK-21 cells to which this virus demonstrated more distinct cytopathic effects. The reciprocal of the highest dilution of serum where more than $50 \%$ of the cell sheets remained intact was read as antibody titer. Antibodies tested by this method were 10 - to 16 -fold lower in titer than those obtained from the standard method of $50 \%$ plaque reduction test (Table 1). Both PS and BHK-21 cells disintegrated by $\mathrm{D}-3$ virus did not exfoliate from the well. This made reading of results difficult. The plaque reduction test in a microplate with Vero cell monolayers was used for D-3 virus. ${ }^{23}$ Dilution of serum started at $1: 16$ because most survey sera were short in amounts owing to the preceding antibody examinations. Sera which reduced plaques $90 \%$ and more was taken as positive.

\section{Collection of Mosquitoes}

Mosquitoes were collected in February and March of 1975 at the following seven Indonesian localities surrounding Wallace's Line: Samarinda, Balikpapan, Surabaya, Bali, Lombok, Ujung Pandang, and Pomalaa. Adult mosquitoes were sampled by outdoor collections using cattle as bait or using a double mosquito-net for 1 or 2 hours after sunset. Mosquitoes resting indoors were also sampled at few localities. Mosquito larvae and pupae were sampled mainly at paddy fields, swamps, ditches, and water containers. After the taxonomic examinations, some of the mosquitoes were sent to Department of Entomology, National Museum of Natural History, Smithsonian Institution, Washington, D.C., U.S.A., to confirm our identification.

RESULTS

\section{Antibody Prevalence}

All subjects in Chiang Mai were children and young adults while those in Bangkok were mostly
TABLE 1

Comparisons between arbovirus antibody titers in hyperimmune rabbit sera tested by the microneutralization test (MNT) and $50 \%$ plaque reduction neutralization test (PRNT)

\begin{tabular}{|c|c|c|c|c|c|}
\hline Virus & Strain & Cell & PRNT & MNT & $\begin{array}{l}\text { PRNT/ } \\
\text { MNT }\end{array}$ \\
\hline $\begin{array}{l}\text { Japanese } \\
\text { encephalitis }\end{array}$ & $\begin{array}{l}\text { JaGAr01 } \\
\text { JaGAr01 } \\
\text { Nakayama }\end{array}$ & $\begin{array}{c}\text { PS } \\
\text { BHK-21 } \\
\text { PS }\end{array}$ & $\begin{array}{l}8,000 \\
8,000 \\
2,000\end{array}$ & $\begin{array}{l}800 \\
480 \\
160\end{array}$ & $\begin{array}{l}10 / 1 \\
16 / 1 \\
12 / 1\end{array}$ \\
\hline Dengue-2 & Trinidad & BHK-21 & 1,000 & 64 & $16 / 1$ \\
\hline Negishi* & $\begin{array}{l}\text { Exp. } 1 \\
\text { Exp. } 2\end{array}$ & $\begin{array}{l}\text { PS } \\
\text { PS }\end{array}$ & $\begin{array}{l}1,600 \\
1,600\end{array}$ & $\begin{array}{l}160 \\
128\end{array}$ & $\begin{array}{l}10 / 1 \\
12 / 1\end{array}$ \\
\hline
\end{tabular}

* Data from Hashimoto et al..$^{22}$

adults and the aged. The subjects in both cities were considered together in the same group to cover a wide range of age, and their locality was called "Thailand" in the present study. Of persons from whom serum samples were collected in Surabaya, only those under 20 years of age were chosen as the subjects because life histories of older persons were ambiguous. All subjects from Australia were natives of north Queensland. The number of subjects in each age group differed in several localities. Therefore, antibody rates over all ages were standardized using a population of 25 persons in each 10-year age group, and the standardized antibody rate (Rst) was compared between localities. The results are summarized in Tables 2 and 3.

Sindbis and GET virus antibodies were rare in every locality except for Queensland, where $11 \%$ and $5 \%$ of sera reacted with the viruses, respectively. CHIK virus antibody was widely distributed in the study area, but the highest prevalence was observed in sera from Samarinda and Balikpapan. It will be noted that there were few positive reactors to $\mathrm{CHIK}$ in the two localities of the Australian zoogeographic region and also in Bali and Lombok. RR virus antibody was confined largely to the Australian region. New Guinean aborigines in Pit River, which is at an altitude of $2,600 \mathrm{~m}$, were devoid of the four group A arbovirus antibodies.

Neutralization tests with the six group B arboviruses were carried out for all survey sera except those from Queensland which were cytotoxic at a dilution $1: 100$ or more even after dialysis. D-2 and D-3 virus antibodies were widespread in the study area, although the survey of D-3 antibody 
TABLE 2

Prevalence of hemagglutination-inhibiting antibody to four alphaviruses, Sindbis (SIN), Getah (GET), chikungunya (CHIK), and Ross River (RR), in human sera

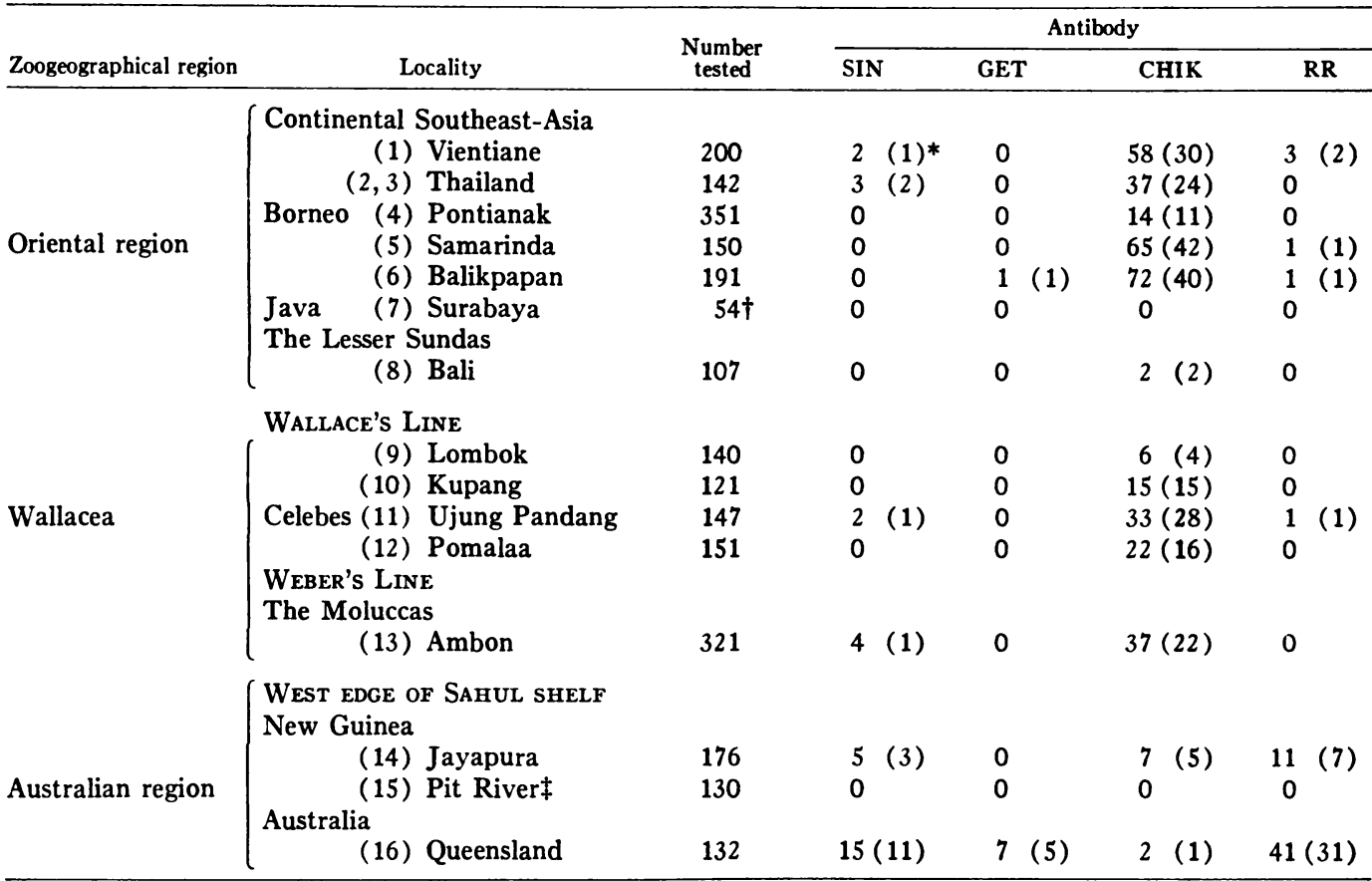

Number positive $(\geq 1: 10)$. The numeral in the parentheses indicates the standardized antibody rate (Rst) over all ages.

$\dagger$ All subjects were less than 20 years old.

was limited in locality. JE virus antibody was prevalent with different frequencies in the Oriental zoogeographic region, but was relatively low in Lombok. It will be noted that there was an abrupt decline of JE antibody prevalence to negligible levels in Wallacea and Australian region. Antibodies to MVE and KUN viruses were widespread and occurred at a moderate frequency. EH antibody, on the other hand, had a limited distribution and was confined mostly to Jayapura.

\section{Specificity of Antibodies}

Although the great majority of survey sera reacted singly with one of the four group A arboviruses in the $\mathrm{HI}$ test, those remaining reacted with two or more of the viruses. Some of the multi-positive sera are presented in Table 4. Seven sera from Vientiane, Samarinda, Balikpapan, and Ujung Pandang were distinctly higher in titer to CHIK virus. The fact that many sera from these localities reacted only with CHIK and those positive to other viruses were rare suggests that CHIK antibody was specific among antibodies in the multi-positive sera. The reverse was true for antibody titers in the three Queensland sera. Specific antibodies only to $R R$ and SIN viruses were found in these sera. Sera singly-positive to SIN virus were scattered in Thailand, Ujung Pandang, Ambon, Jayapura, and Queensland. None of the survey sera reacted singly with GET. There were eight sera multi-positive to GET and other viruses, but they were always lower in titer against GET.

Multi-reactors occurred with higher frequency to group $\mathrm{B}$ arboviruses, especially to $\mathrm{D}-2, \mathrm{JE}$, MVE, and KUN. This could be due to antigenic crossings between or sequential infections with the viruses. We attempted to identify virusspecific antibody as follows: sera tested for the four viruses were grouped by highest antibody titer to a given virus. Similarly, sera singlypositive to the same virus were grouped, and sera of both groups were compared for their prevalence 
ARBOVIRUS ANTIBODIES IN INDONESIA

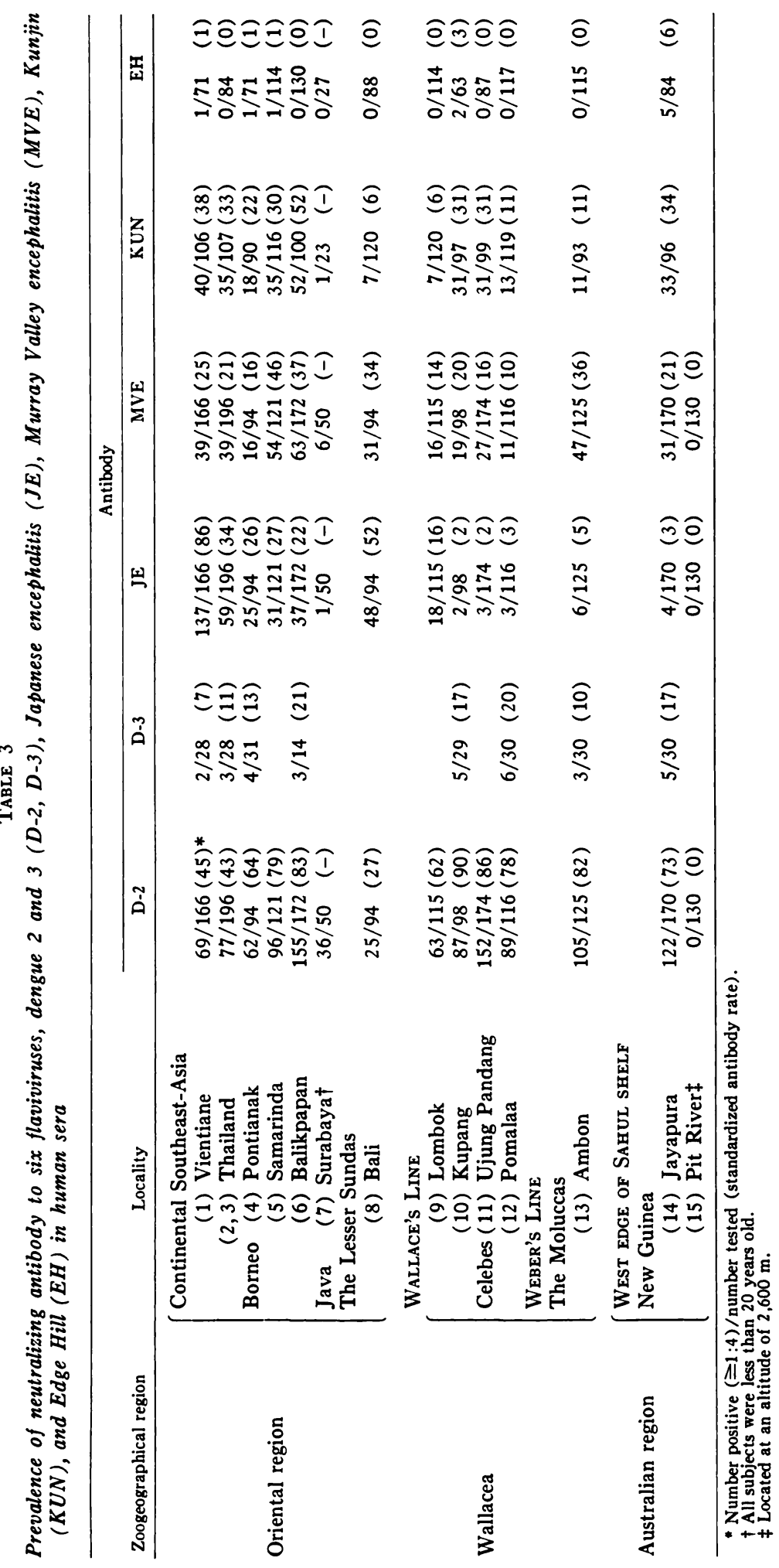


TABLE 4

Comparisons between group $A$ arbovirus antibody titers in multi-positive sera

\begin{tabular}{|c|c|c|c|c|c|c|}
\hline \multirow[b]{2}{*}{ Locality } & \multirow{2}{*}{$\begin{array}{c}\text { Serum } \\
\text { no. }\end{array}$} & \multirow{2}{*}{$\begin{array}{c}\text { Age } \\
\text { (yrs) }\end{array}$} & \multicolumn{4}{|c|}{ Antibody* } \\
\hline & & & SIN & GET & CHIK & $\mathbf{R R}$ \\
\hline \multirow[t]{3}{*}{ Vientiane } & L-120 & 49 & $0 \dagger$ & 0 & 80 & 20 \\
\hline & L-180 & 67 & 0 & 0 & 80 & 10 \\
\hline & L-216 & 20 & 0 & 0 & 40 & 10 \\
\hline Samarinda & S-140 & 54 & 0 & 0 & 80 & 20 \\
\hline \multirow[t]{2}{*}{ Balikpapan } & B-122 & 15 & 0 & 10 & 160 & 0 \\
\hline & B-96 & 53 & 0 & 0 & 80 & 20 \\
\hline Ujung Pandang & U-196 & 60 & 40 & 0 & 80 & 10 \\
\hline \multirow[t]{3}{*}{ Queensland } & A-3455 & 32 & 80 & 20 & 40 & 80 \\
\hline & A-967 & 39 & 0 & 20 & 0 & 80 \\
\hline & A-1473 & 43 & 80 & 0 & 20 & 20 \\
\hline
\end{tabular}

* SIN, Sindbis; GET, Getah; CHIK, chikungunya; RR, Ross River. $: 10$.

in localities. Sera multi-positive to the viruses with same titer were excluded from the study. The results are shown in Table 5 .

The numbers of sera in the paired groups were proportional to each other in almost every locality. The results suggested that sera with the highest antibody titer in multi-positive specimens would indicate homologous virus infection. D-2 virus is antigenically related to other types of dengue viruses, ${ }^{1}$ and, therefore, the D-2 antibody in the survey sera is thought to be an indication of infection with any of the dengue viruses. Antibodies ascribable to MVE and KUN virus infections were few in every locality. This would mean low prevalence of both viruses, but the possibility that high-titered heterologous virus antibody in the serum masked the presence of virus-specific antibody must also be taken into consideration. Serum singly-positive to $\mathbf{E H}$ virus was absent. Ten sera were multi-positive to $\mathrm{EH}$ and other viruses (Table 6). Of the ten, only one from Jayapura, JH-107, had a higher titer to EH. However, considering the low cross-reactivity between $\mathrm{EH}$ and other group B arboviruses in the neutralization test, ${ }^{24} \mathrm{EH}$ antibody in another serum from Jayapura, JH-101, might also be specific.

\section{Age Distribution of Antibodies}

Of the four group A arbovirus antibodies, only those to CHIK and RR viruses were high enough in prevalence to study age distribution. The data are shown in Table 7. The age distribution of CHIK antibody in Vientiane would mean that

TABLE 5

Geographic distribution of sera singly-positive to a given group $B$ arbovirus and those multi-positive with highest titer to the same virus*

\begin{tabular}{|c|c|c|c|c|c|}
\hline \multirow[b]{2}{*}{ Region } & \multirow[b]{2}{*}{ Locality } & \multicolumn{4}{|c|}{ Antibodyt } \\
\hline & & D-2 & JE & MVE & KUN \\
\hline Oriental region & $\begin{array}{l}\text { Vientiane } \\
\text { Pontianak } \\
\text { Samarinda } \\
\text { Balikpapan } \\
\text { Surabaya§ } \\
\text { Bali }\end{array}$ & $\begin{array}{l}37(2) \ddagger \\
18(27) \\
40(30) \\
55(36) \\
4(16) \\
22(3)\end{array}$ & $\begin{aligned} 13 & (17) \\
0 & (2) \\
1 & (0) \\
0 & (0) \\
0 & (0) \\
3 & (19)\end{aligned}$ & $\begin{array}{ll}0 & (0) \\
0 & (2) \\
2 & (1) \\
4 & (1) \\
1 & (0) \\
1 & (1)\end{array}$ & $\begin{array}{ll}0 & (0) \\
1 & (1) \\
0 & (2) \\
0 & (0) \\
0 & (0) \\
0 & (1)\end{array}$ \\
\hline Wallacea & $\begin{array}{l}\text { Wallace's LnNe } \\
\text { Lombok } \\
\text { Kupang } \\
\text { Ujung Pandang } \\
\text { Pomalaa } \\
\text { WeBER's LINE } \\
\text { Ambon }\end{array}$ & $\begin{array}{l}13(50) \\
20(24) \\
39(45) \\
14(70) \\
25(49)\end{array}$ & $\begin{array}{ll}5 & (0) \\
0 & (0) \\
0 & (0) \\
0 & (0) \\
0 & (0)\end{array}$ & $\begin{array}{ll}1 & (0) \\
0 & (0) \\
0 & (0) \\
1 & (1) \\
0 & (1)\end{array}$ & $\begin{array}{ll}0 & (0) \\
0 & (1) \\
0 & (0) \\
0 & (3) \\
0 & (1)\end{array}$ \\
\hline Australian region & $\begin{array}{l}\text { SAHUL SHELF } \\
\text { Jayapura }\end{array}$ & $28(17)$ & $0(0)$ & $0(0)$ & 0 (5) \\
\hline
\end{tabular}

* The results on sera from Thailand were excluded as the starting dilution of the sera differed with tests for D-2 antibody and three other virus antibodies.

$\dagger \mathrm{D}-2$, dengue $2 ; \mathrm{JE}$, Japanese encephalitis virus; MVE, Murray Valley encephalitis virus; KUN, Kunjin.

₹ Number of multi-positive sera with highest titer to respective viruses. The number of sera singly-positive to the same virus is

§ All subjects were less than 20 years old. 
TABLE 6

Comparisons between antibody titers of sera multi-positive to Edge Hill (EH) and other group B arboviruses*

\begin{tabular}{lccccccc}
\hline & & & \multicolumn{5}{c}{ Antibody } \\
\cline { 4 - 8 } Locality & Serum number & Age (yrs) & EH & D-2 & JE & MVE & KUN \\
\hline Vientiane & L-181 & 31 & 4 & 32 & $>32$ & $0 \dagger$ & 8 \\
Pontianak & P-26 & 19 & 8 & $>32$ & N.D. & 0 & 0 \\
Samarinda & S-122 & 63 & 8 & 16 & 8 & 8 & 0 \\
Kupang & T-28 & 7 & 4 & 16 & 0 & 0 & 0 \\
& T-243 & 50 & 4 & 16 & 0 & 4 & 0 \\
Jayapura & JH-101 & 39 & 16 & 32 & 0 & 8 & $>32$ \\
& JH-103 & 50 & 4 & 32 & 0 & 0 & 8 \\
& JH-107 & 50 & $>32$ & 32 & 0 & 8 & 8 \\
& JH-111 & 43 & 4 & 32 & 4 & 8 & 8 \\
& JH-120 & 32 & 8 & 16 & 16 & 0 & 8 \\
\hline
\end{tabular}

* D-2, dengue 2; JE, Japanese encephalitis; MVE, Murray Valley encephalitis; KUN, Kunjin.

$\ddagger$ N.D., not determined.

this virus has been active there for many years. A similar age pattern in distribution of CHIK antibody was observed for Thailand sera. In Balikpapan, CHIK antibody rates were remarkably high over all ages, and the same was true in Samarinda, suggesting epidemic spread of CHIK virus among residents in recent years. In Pontianak, Kupang, Pomalaa, and Ambon, CHIK antibody was rare or absent in persons aged under 30 , but beyond 30 years of age it increased precipitously in prevalence with increasing age. A similar age pattern in distribution of the antibody could be seen for Ujung Pandang and Lombok. In Surabaya, no CHIK antibody was observed, but all of the sera were from persons less than
20 years of age. These results suggest that CHIK virus has been inactive for about 30 years, before which it was highly active. Age distribution of RR antibody suggests high $R R$ virus activity in Queensland. SIN antibody, which was the next highest in prevalence there, showed an age pattern similar to RR antibody. The data suggest low $R R$ virus activity in Jayapura.

Of the six group $B$ arbovirus antibodies, the age distribution of antibodies to D-2, JE, MVE, and KUN viruses were studied. In view of the possibility of the presence in multi-positive sera of virus-specific antibody masked by high-titered heterologous virus antibody, all sera positive to the respective viruses were included regardless of

TABLE 7

Age distribution of antibodies to chikungunya (CHIK) and Ross River (RR) viruses in selected localities

\begin{tabular}{lllcrrrrr}
\hline & & \multicolumn{7}{c}{ Age } \\
\cline { 3 - 8 } Antibody & Locality & $0-9$ & $10-19$ & $20-29$ & $30-39$ & $40-49$ & $50+$ \\
\hline CHIK & Vientiane & $3 / 42(7) *$ & $4 / 36(11)$ & $4 / 27(15)$ & $9 / 26(35)$ & $11 / 22(50)$ & $22 / 47(47)$ \\
& Balikpapan & $10 / 28(36)$ & $21 / 43(49)$ & $13 / 48(27)$ & $10 / 24(42)$ & $8 / 24(33)$ & $10 / 24(42)$ \\
& Pontianak & $0 / 104(0)$ & $0 / 107(0)$ & $0 / 65(0)$ & $5 / 42(12)$ & $5 / 20(25)$ & $4 / 13(31)$ \\
& Kupang & $0 / 18(0)$ & $1 / 23(4)$ & $0 / 28(0)$ & $4 / 24(17)$ & $3 / 10(30)$ & $7 / 18(39)$ \\
& Pomalaa & $0 / 25(0)$ & $0 / 32(0)$ & $0 / 24(0)$ & $3 / 24(12)$ & $10 / 23(43)$ & $9 / 23(39)$ \\
& Ambon & $0 / 96(0)$ & $5 / 106(5)$ & $2 / 51(4)$ & $12 / 34(35)$ & $4 / 12(33)$ & $12 / 22(54)$ \\
& Jayapura & $0 / 23(0)$ & $0 / 49(0)$ & $3 / 31(10)$ & $0 / 20(0)$ & $0 / 19(0)$ & $0 / 24(0)$ \\
& Queensland & $0 / 20(0)$ & $0 / 23(0)$ & $0 / 23(0)$ & $0 / 21(0)$ & $0 / 22(0)$ & $0 / 23(0)$ \\
RR & Jayapura & $1 / 33(3)$ & $0 / 49(0)$ & $3 / 31(10)$ & $2 / 20(10)$ & $1 / 19(5)$ & $4 / 24(17)$ \\
& Queensland & $1 / 20(5)$ & $5 / 23(22)$ & $7 / 23(30)$ & $10 / 21(48)$ & $8 / 22(36)$ & $10 / 23(43)$ \\
\hline
\end{tabular}

* Number positive/number tested (percent positive). 


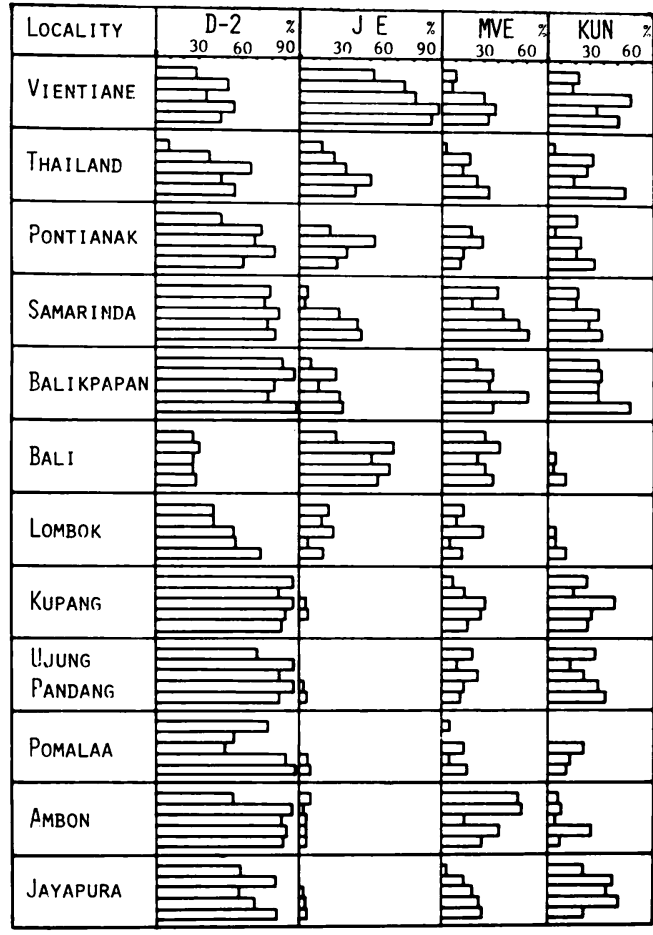

Figure 2. Age distribution of group $B$ arbovirus antibodies. Each histogram indicates percentage positive in 10-year age groups from 0-9 (top) to 40 and over (bottom).

their antibody levels. The results are shown in Figure 2.

Dengue-2 antibody rates were very high even in the age group under 10 years in almost every locality, indicating high dengue virus activity. Similarly, the data suggest high JE virus activity in areas west of Wallace's Line. The age pattern of JE antibody distribution in Lombok indicates that this virus is not endemic there. JE antibody in sera from other localities was not specific. It will be noted that D-2 antibody rates were lower over all ages in localities with high JE antibody rates, and vice versa. As mentioned above, identification of antibody ascribable to MVE and KUN virus infections were usually difficult. However, remarkably high MVE antibody rates were observed in persons under 20 years of age in Ambon, suggesting that this virus was active in recent years. Similarly, the paucity of KUNpositives over all ages in Bali and Lombok probably means that this virus has been almost inactive for many years.
Vector Relationships and Geographic Distribution of Arbovirus Antibodies

Thousands of mosquito samples were collected in the seven Indonesian localities surrounding Wallace's Line. Entomologic study of the mosquitoes will be reported in a separate paper. Distribution in the localities of the mosquitoes assumed as vectors of the ten group A and B arboviruses is shown in Table 8 . Numbers of mosquitoes varied in different localities with the time and manpower used for the collection. Limitations of some Aedes mosquitoes to few localities may be explained by the collection having been carried out mainly outdoors. Aedes and Culex mosquitoes are broadly distributed on both sides of Wallace's Line. Despite detailed examinations, Aedes vigilax and Culex annulirostris, which are believed to be main vectors of many Australian arboviruses, ${ }^{25}$ were absent in our collections.

Even though the mosquito data are limited, a basic understanding of the vector relationships may be obtained by comparing the results of the mosquito survey to Tables 2 and 4 for group $A$ arboviruses, and Tables 3 and 5 for group B.

Potential vectors of SIN and GET viruses had a wide distribution, but antibodies to the two viruses were rare. CHIK antibody prevalence in the area differed with age; however, if age groups 30 and older were taken, the antibody was consistent in distribution with vectors. The failure to collect potential vectors of $R R$ and $E H$ viruses was also consistent with the absence of antibodies specific to the viruses. D-2 and D-3 antibodies had a high prevalence even though the distribution of Aedes aegypti and Aedes albopictus was limited, an indication that our mosquito collections were not thorough. Both of these mosquito species are known to have a wide distribution in Indonesia and the Pacific.

Potential vectors of JE virus were also widespread, but virus-specific antibody was almost confined to localities west of Wallace's Line, suggesting that Oriental animals may be important in distribution of the virus. Potential vectors of KUN virus had a widespread distribution which was consistent with the presence of virus-specific antibody although at a very low frequency. Culex bitaeniorhynchus, a potential vector of MVE virus, was widespread in every locality where virus-specific antibody was scattered. 
TABLE 8

Distribution of potential vectors collected in seven localities surrounding Wallace's Line

\begin{tabular}{|c|c|c|c|c|c|c|c|}
\hline \multirow[b]{3}{*}{ Potential vector } & \multicolumn{7}{|c|}{ Locality* } \\
\hline & \multicolumn{4}{|c|}{ West of Wallace's Line } & \multicolumn{3}{|c|}{ East of Wallace's Line } \\
\hline & SAM & BLP & SUR & BAL & LOM & UP & POM \\
\hline Anopheles barbirostris group (JE) $\dagger$ & + & + & - & + & + & - & + \\
\hline Aedes aegypti (CHIK, dengue) & + & - & - & - & - & + & - \\
\hline A. albopictus (CHIK, dengue) & - & + & - & + & - & + & + \\
\hline A. vexans (GET, JE) & - & - & - & - & - & + & - \\
\hline A. vigilax ( $\mathrm{RR}, \mathrm{EH})$ & - & - & - & - & - & - & - \\
\hline Culex annulus (JE) & + & + & + & + & + & + & + \\
\hline C. bitaeniorhynchus (SIN, GET, MVE) & + & + & + & + & + & + & + \\
\hline C. tritaeniorhynchus (SIN, GET, CHIK, JE) & + & + & + & + & + & + & + \\
\hline C. gelidus (GET, CHIK, JE, KUN) & + & + & - & - & - & + & + \\
\hline C. pipiens fatigans (SIN, CHIK, JE) & - & + & + & - & - & + & + \\
\hline C. pseudovishnui (SIN, JE, KUN) & - & + & - & + & + & - & + \\
\hline C. annulirostris (SIN, RR, MVE, KUN, EH) & - & - & - & - & - & - & - \\
\hline
\end{tabular}

- SAM, Samarinda; BLP, Balikpapan; SUR, Surabaya; BAL, Bali; LOM, Lombok; UP, Ujung Pandang: POM, Pomalaa.

$\dagger$ Arbovirus presumably transmitted by the mosquito.JE, Japanese encephalitis; CHIK, chikungunya; GET, Getah; RR, Ross River; EH, Edge Hill; SIN, Sindbis; MVE, Murray Valley encephalitis.

\section{DISCUSSION}

Although the HI test is quite sensitive for detecting arbovirus antibodies, cross-reactions of ten occur among the viruses of the same groups. ${ }^{2}$ For this reason the neutralization test has been recommended for serologic surveys for viruses. ${ }^{13}$ However, a great majority of sera used for the present study reacted with only one of the four alphaviruses by the HI test. This greatly facilitated interpretation of the results. Multi-positive sera can also be useful if antibody highest in titer is taken. SIN antibody was found at a rate of about $11 \%$ of sera from Queensland where repeated isolation of the virus from mosquitoes has been reported. ${ }^{25}$ However, SIN antibody was rare or absent in many other localities where vectors are known to exist. ${ }^{20.27}$ The absence in human serum of SIN antibody has also been reported in Manila, Sarawak, and Australasia where wild and domestic birds have high antibody rates. ${ }^{28-31} \mathrm{We}$ failed to detect GET virus-specific antibody in the survey sera. A high GET antibody prevalence has been reported in New Guinean aborigines, ${ }^{32}$ but this finding must be accepted with caution because the present survey indicated the presence of RR virus which is antigenically related to GET. At any rate, SIN and GET antibodies in human serum do not portray the activity of the viruses. Presumably, they survive mainly in a bird-mosquito cycle.

In contrast, CHIK antibody in human serum is useful to study the distribution and prevalence of the virus. The present survey suggests that CHIK virus has been widely distributed in the Oriental region and Wallacea, but rare in west New Guinea and absent in north Australia. The presence in the Australian zoogeographic region of vectors of $\mathrm{CHIK}$ virus is recognized, ${ }^{25 .}{ }^{33}$ suggesting the absence in the region of vertebrate hosts of the virus. Monkeys are believed to be the main vertebrate host of CHIK virus in Africa. ${ }^{2}$ Although various kinds of monkeys live in Sumatra, Borneo, and Java, monkeys in Celebes are limited to two genera of Macaca and Cynopithecus. ${ }^{15}$ Only Cynopithecus monkeys are recognized in Moluccas, and Cynomolgus in the Lesser Sundas. No wild monkeys are said to live in the Australian zoogeographic region. ${ }^{16}$ From these facts, CHIK virus seems to be very close in distribution to that of monkeys. Two pieces of serologic evidence contradict the hypothesis incriminating monkeys as a vertebrate host of CHIK virus in this area. One is the paucity of positive reactors to CHIK in Bali and Lombok where habitation of wild monkeys is recognized. The paucity of CHIK-positives in Lombok has been reported previously. ${ }^{9}$ The other is the peculiar age pattern of CHIK antibody distribution in many Indonesian localities; that is, the antibody was rare or absent in residents under age 30 , but beyond 30 years of age it increased precipitously in prevalence with increasing age. 
This would mean that $\mathrm{CHIK}$ virus has been inactive for about 30 years, before which it was highly active. Chronologically, residents who were at ages 30 and more at the time of bleeding were born in or before 1945 when the Second World War ended in this area. Many foreign troops nonimmune against $\mathrm{CHIK}$ came to and stayed in Indonesia after stationing in continental Southeast Asia where CHIK was endemic. It is possible that the troops could have brought CHIK virus into the country to spread it among residents, and the virus faded out there with repatriation of the troops after the end of the war. According to this assumption, CHIK virus may have been absent in most Indonesian localities before the war, and monkeys would not be natural hosts of the virus in the area. Reasons why CHIK virus thus introduced into the area was not maintained, however, are obscure.

Very high CHIK antibody prevalence over all ages in Samarinda and Balikpapan suggests epidemic spread of the virus among residents in recent years. In fact, a severe epidemic of febrile disease occurred there in 1973 (Dr. Djamas E. Harahap, Center for Biomedical Research, Ministry of Health, Indonesia, personal communication). We diagnosed this disease as CHIK by examination of antibody in sera from patients and contacts just after the epidemic. ${ }^{18}$ A large amount of timber had been brought by truck from remote forests to both cities for shipment. It is conceivable that the trucks also brought $\mathrm{CHIK}$ virusinfected mosquitoes from the forests; alternatively, the virus may have been introduced from abroad.

Ross River virus-specific antibody was found only in Jayapura and Queensland where presumed vectors are prevalent. Marsupials, believed to be the main vertebrate host of $R R$ virus, are also confined to the Australian zoogeographic region except for few species of Phalanger. ${ }^{15}$ Distribution in areas west of Weber's Line of Australian murid rodents of the subfamily, Pseudomys novahollandiae, and of Australian fruit bats, Pteropus poliocephalus, which are both thought to be potential hosts of $R R$ virus, is still obscure. ${ }^{34}$

From a serologic viewpoint, westward extension of $R R$ virus is limited by the western marginal line of Sahul shelf which also forms a barrier against eastward extension of CHIK virus. Sahulland was separated from Sundaland at the late Cretaceous period. ${ }^{35}$ The water gap between the
Sahul shelf and Wallacean islands has remained open despite the violent geological activity and repeated glaciations during the Cenozoic period when mammals and birds evolved in large part. ${ }^{14-16}$ These facts would explain why CHIK and RR virus antibodies were limited in distribution by the same zoogeographic line.

The microneutralization test was 10- to 16 -fold less in sensitivity than the $50 \%$ plaque reduction neutralization test for detecting group $B$ arbovirus antibodies. However, it is known that plaquereducing antibody rises in titer usually to $1: 40$ or more to the causative virus, and maintains a high titer by subsequent infections with homologous and heterologous viruses. Arbovirus antibody with such levels was also detected with high reproducibility by the microneutralization test. Moreover, the relatively low sensitivity of the test had the advantage of reducing cross-reactions with heterologous viruses which make interpretation of results difficult.

The serologic data indicate that dengue viruses are highly prevalent in areas between Laos and west New Guinea. Vector mosquitoes are also widespread in the area. ${ }^{2636}$ Besides man, monkeys are suspected as a possible host of the viruses. ${ }^{7}$ However, epidemic outbreaks of dengue have been reported in north Australia where monkeys are believed to be absent. The main host of dengue viruses in the study area is probably man, whose habitation is unrestricted by the zoogeographic divisions.

Although JE virus has been isolated from various countries of Southeast Asia and adjacent areas, $^{1,2}$ its distribution in the Indo-Australian archipelago is almost unknown. The present survey demonstrated serologically that $\mathrm{JE}$ virus has been active in areas west of Wallace's Line. About $16 \%$ of sera from Lombok contained JE antibody, but the age pattern of the antibody distribution differed from that in endemic areas of JE. A significant proportion of residents in Lombok are Hindu, and it may be that much of the antibody in Lombok sera were acquired in Bali which is a holy place for Hindus. The failure to detect JE virus-specific antibody in areas east of Wallace's Line despite the presence of vectors may mean the absence of vertebrate hosts. Domestic animals which act as a host of $\mathrm{JE}$ virus such as swine are widely distributed in the area although their density may differ with localities. Of the wild animals, particular interest 
has been directed to ardeids since they have high sensitivity to JE virus and are highly mobile. ${ }^{37}$ They have a widespread distribution from tropical to temperate Asia, and migrate between summer and winter residences. Considering their wide sphere of action, neither the Macassar nor Lombok straits, where Wallace's Line runs, appear to be strong barriers against their movement. Most Oriental animals without activity to fly would have become extinct from Wallacea during the Tertiary period of Cenozoic era. ${ }^{14,38,39}$ On the assumption that some of the animals would be hosts of JE virus, the limited distribution of JE antibody could be understood.

In tropical areas where dengue is highly endemic, severe diseases due to other group B arboviruses rarely occur. The reverse is the case in temperate areas. The rare occurrence of epidemic dengue in temperate areas can be explained on the absence of winter carry-over mechanisms of the virus. ${ }^{40}$ However, we found a tendency that dengue antibody prevalence was low in localities with high JE antibody prevalence, and vice versa. This would mean that epidemic dengue is also rare in tropical areas where the mechanisms operate year-round, if JE is highly endemic there.

Antibody ascribable to MVE virus infection was found in 17 sera from the Oriental region and Wallacea where isolation of the virus has not yet been reported. Culex annulirostris, the main vector of MVE virus in Australia, was absent in our collections; however, Culex bitaeniorhynchus, another possible vector, is widespread in the area. 1. 26.41 Although Wallace's and Weber's lines interfere with the westward extension of Australian birds, ${ }^{14}$ it is unlikely that both lines form a complete barrier to viremic birds which transport MVE virus to susceptible vectors and vertebrate hosts in the Oriental region and Wallacea. Isolation of virus from these animals in the areas would verify the MVE antibody distribution.

Kunjin virus was first isolated in Australia, and subsequently in Sarawak. ${ }^{\text {2.48 }}$ Our serologic evidence suggests widespread distribution of KUN virus in the Indo-Australian archipelago. This is supported by the wide distribution in the area of Culex pseudovishnui, the main vector of $\mathrm{KUN}$ virus in Sarawak, and also of domestic fowl and cattle which are both assumed as a vertebrate host of the virus. ${ }^{42-45}$

Edge Hill virus has been isolated only in
Australia, which is consistent with the limited distribution of its main vertebrate hosts (marsupials) and vectors (Aedes vigilax and Culex anmulirostris). Thus, our failure to detect $\mathrm{EH}$ virus-specific antibody in sera from the Oriental region and Wallacea was not unexpected. However, EH antibody was detected in a few sera from Jayapura (west New Guinea), similar to some Australian localities where animals have high antibody rates. ${ }^{45}$ Presumably, this virus survives mainly in a marsupial-mosquito cycle.

New Guinean aborigines in Pitt River were devoid of antibodies to the seven group A and B arboviruses. This village is at an altitude of 2,600 $\mathrm{m}$ and is said to be free from malaria (Dr. M. L. Simons, Director of WHO Immunology Research and Training Center, Singapore, personal communication). Climatic conditions at such a high altitude make it less likely that the mosquitoes, if they did occur, would be able to transmit arboviruses.

\section{ACKNOWLEDGMENTS}

The authors express thanks to Dr. Pien Chiowanich and Dr. Prakorb Tuchinda for supplying Siamese sera; Dr. Shingo Yamaguchi for Laosian sera; Dr. M. J. Simons for sera of New Guinean aborigines; Dr. Ralph L. Doherty for sera of natives in Queensland; and Dr. Djamas E. Harahap, Dr. Pohan Bosman, and many other Indonesian colleagues for collecting Indonesian sera. We are also indebted to Dr. Akira Oya, Dr. Akira Igarashi, Dr. Robert E. Shope, and Dr. Ralph L. Doherty for providing arbovirus strains. Particular thanks are expressed to Dr. Y. M. Huang, Mr. E. L. Peyton and Dr. S. Sirivanakarn, Smithsonian Institution, for identifying some of our mosquito samples; staffs of our laboratories for technical assistance in serologic tests; and Dr. Duane J. Gubler, NAMRU-2, Jakarta, for giving helpful advice on preparation of this report.

\section{REFERENCES}

1. Berge, T. O., 1975. International Catalogue of Arboviruses. U.S. Department of Health, Education, and Welfare, Washington, D.C.

2. Theiler, M., and Downs, W. G., 1973. The Arthropod-borne Viruses of Vertebrates. Yale University Press, New Haven.

3. Sabin, A. B., 1959. Survey of knowledge and problems in the field of arthropod-borne virus infections. Arch. Ges. Virusforsch., 9: 1-10. 
4. Mattingly, P. F., 1960. Origin and evolution of viruses. II. Ecological aspects of the evolution of mosquito-borne virus diseases. Trans. $R$. Soc. Trop. Med. Hyg., 54: 97-112.

5. Smith, C. E. G., 1960. Origin and evolution of viruses. III. Factors in the past and future evolution of the arboviruses. Trans. R. Soc. Trop. Med. Hyg., 54: 113-129.

6. Lvov, D. K., and Lebedev, A. D., 1970. On evolution of arboviruses. Vop. Virusol., 15: 372-376.

7. Miles, J. A. R., 1964. Some ecological aspects of the problem of arthropod-borne animal viruses in the western Pacific and South-east Asia regions. Bull. W.H.O., 30: 197-210.

8. Pond, W. L., 1963. Arthropod-borne virus antibodies in sera from residents of South-east Asia. Trans. R. Soc. Trop. Med. Hyg., 57: 364-371.

9. Hotta, S., Aoki, H., Samoto, S., Yasui, T., and Kawabe, M., 1970. Virologic-epidemiological studies on Indonesia: II. Measurement of antiarbovirus antibodies in sera from residents of Lombok, South Sumatra and West Java, in comparison with results concerning sera from residents of Japanese main islands. Kobe $J$. Med. Sci., 16: 215-234.

10. Hotta, S., Aoki, H., Samoto, S., Yasui, T., and Noerjasin, B., 1970 . Virologic-epidemiological studies on Indonesia: III. HI antibodies against selected arboviruses (groups $\mathrm{A}$ and $\mathrm{B}$ ) in human and animal sera collected in Surabaya, East Java, in 1968. Kobe J. Med. Sci., 16: $235-250$.

11. Rao, T. R., 1971. Immunological surveys of arbovirus infections in South-east Asia, with special reference to dengue, chikungunya and Kyasanur Forest disease. Bull. W.H.O., 44: 585-591.

12. Doherty, R. L., 1974. Arthropod-borne viruses in Australia and their relation to infection and disease. Progr. Med. Virol., 17: 136-192.

13. Tesh, R. B., Gajdusek, D. C., Garruto, R. M., Cross, J. H., and Rosen, L., 1975. The distribution and prevalence of group $A$ arbovirus neutralizing antibodies among human populations in Southeast Asia and the Pacific Islands. Am. J. Trop. Med. Hyg., 24: 664-675.

14. Mayr, E., 1944. Wallace's Line in the light of recent zoogeographic studies. Q. Rev. Biol., 19: 1-14.

15. Darlington, P. J., Jr., 1957. Zoogeography. John Wiley \& Sons, New York.

16. Wilma, G., 1962. Animal Geography. Heinemann, London.

17. Zeuner, F. E., 1941. The biogeographic division of the Indo-Australian archipelago: 7. The divisions as indicated by the distribution of insects in relation to geology. Proc. Linnean Soc. London, 154th session, 157-163.

18. Kanamitsu, M., Fukuhara, M., Tamura, H., Ishizawa, F., Ogata, T., Yoshida, I., Yoshioka, I., and Saroso, J. S., 1973. Serologic survey of the geographic distribution of arbovirus antibodies among residents in Southeast Asia. Virus (Proc. 21st Annu. Meetings, Soc. Jap. Virol.), 23: 353.

19. Mussgay, M., and Rott, R., 1964. Studies on the structure of a hemagglutinating component of a group $\mathrm{A}$ arbovirus (Sindbis). Virology, 23: 573-581.

20. Clarke, D. H., and Casals, J., 1958. Techniques for hemagglutination and hemagglutinationinhibition with arthropod-borne viruses. $\mathrm{Am}$. J. Trop. Med. Hyg., 7: 561-573.

21. De Madrid, A. T., and Porterfield, J. S., 1969 A simple micro-culture method for the study of group B arboviruses. Bull. W.H.O., 40: 113-121.

22. Hashimoto, M., Yamada, K., and Kanamitsu, M., 1971. A microtiter method for assay of neutralizing antibodies against group $B$ arboviruses. Virus, 21 : 55-59.

23. Earley, E., Peralta, P. H., and Johnson, K. M., 1967. A plaque neutralization method for arboviruses. Proc. Soc. Exp. Biol. Med., 125: 741-747.

24. Westaway, E. G., 1965. The neutralization of arboviruses. II. Neutralization in heterologous virus-serum mixtures with four group B arboviruses. Virology, 26: 528-537.

25. Doherty, R. L., 1972. Arboviruses in Australia. Aust. Vet. J., 48: 172-180.

26. Bonne-Wepster, J., 1954. Synopsis of a hundred common non-anopheline mosquitoes of the Greater and Lesser Sundas, the Moluccas and New Guinea. Spec. Publ. R. Trop. Inst. Amsterdam, 111: 1-147.

27. Sirivanakarn, S., 1972. Contributions to the mosquito fauna of Southeast Asia. XIII. The genus Culex, subgenus Eumelanomyia Theobald in Southeast Asia and adjacent areas. Contr. Am. Entomol. Inst., 8: 1-188.

28. Venzon, E. L., 1965. A study of antibody patterns to Australian arboviruses in human sera collected in Manila. Philipp J. Sci., 94: 171178.

29. Simpson, D. I. H., Smith, C. E. G., Bowen, E. T. W., Platt, G. S., and Macdonald, W. W., 1970. Arbovirus infections in Sarawak: Virus isolations from mosquitoes. Ann. Trop. Med. Parasitol., 64: 137-151.

30. Smith, C. E. G., Simpson, D. I. H., Peto, S., Bowen, E. T. W., McMahon, D., Platt, G. S., Way, H., Bright, W. F., and Maidment, B., 1974. Arbovirus infections in Sarawak: Serological studies in man. Trans. $R$. Soc. Trop. Med. Hyg., 68: 96-104.

31. Doherty, R. L., Whitehead, R. H., Wetters, E. J., and Gorman, B. M., 1968. Studies of the epidemiology of arthropod-borne virus infections at Mitchell River Mission, Cape York Peninsula, North Queensland. II. Arbovirus infections of mosquitoes, man and domestic fowls, 1963-1966. Trans. R. Soc. Trop. Med. Hyg., 62: $430-438$. 
32. Wisseman, C. L., Jr., Gajdusek, D. C., Schofield, F. D., and Rosenzweig, E. C., 1964. Arthropod-borne virus infections of aborigines indigenous to Australasia. A preliminary report. Bull. W.H.O., 30: 211-219.

33. Marks, E. N., 1973. An Atlas of Common Queensland Mosquitoes (With a Guide to Common Queensland Biting Midges). University of Queensland Bookshop, Queensland.

34. Gard, G., Marshall, I. D., and Woodroofe, G. M., 1973. Annually recurrent epidemic polyarthritis and Ross River virus activity in a coastal area of New South Wales. II. Mosquitoes, viruses and wildlife. $A m$. J. Trop. Med. Hyg., 22: 551-560.

35. Scrivenor, J. B., 1941. A discussion on the biogeographic division of the Indo-Australian archipelago, with criticism of the Wallace and Weber Lines and of any other dividing lines, and with an attempt to obtain the names used for the divisions. I. Geological and climatic factors affecting the distribution of life in the archipelago. Proc. Linnean Soc., 154th session, 120-126.

36. Huang, Y. M., 1972. Contributions to the mosquito fauna of Southeast Asia. XIV. The subgenus Stegomyia of Aedes in Southeast Asia. I. The scutellaris group of species. Contr. Am. Entomol. Inst., 9: 1-109.

37. Buescher, W. F., Buescher, E. L., and McLure, H. E., 1959. Ecologic studies of Japanese encephalitis virus in Japan. V. Avian factors. Am. J. Trop. Med. Hyg., 8: 689-697.

38. Audley-Charles, M. G., 1973. Relation of Pleistocene migrations of pygmy stegodonts to isolated arc tectonics in eastern Indonesia. Nature, 241: $197-198$.

39. Hooijer, D. A., 1975. Quaternary mammals west and east of Wallace's Line. Netherl. J. Zool., 25: 46-56.

40. Hammon, W. McD., 1969. Observations on dengue fever, benign protector and killer: A Dr. Jekyll and Mr. Hyde. Am. J. Trop. Med. Hyg., 18: $159-165$.

41. Bram, R. A., 1967. Contributions to the mosquito fauna of Southeast Asia. II. The genus Culex in Thailand (Diptera: Culicidae). Contr. Am. Entomol. Inst., 2: 1-296.

42. Doherty, R. L., Carley, J. G., Mackerras, M. J., and Marks, E. N., 1963. Studies of arthropodborne virus infections in Queensland. III. Isolation and characterization of virus strains from wild-caught mosquitoes in North Queensland. Aust. J. Exp. Biol. Med. Sci., 41: 17-30.

43. Bowen, E. T. W., Simpson, D. I. H., Platt, G. S., Way, H. J., and Smith, C. E. G., 1970. Arbovirus infections in Sarawak: The isolation of Kunjin virus from mosquitoes of the Culex pseudovishnui group. Ann. Trop. Med. Parasitol., 64: 263-268.

44. Sanderson, C. J., 1969. A serologic survey of Queensland cattle for evidence of arbovirus infection. Am. J. Trop. Med. Hyg., 18: 433439.

45. Doherty, R. L., Carley, J. G., and Gorman, B. M., 1964. Studies of arthropod-borne virus infections in Queensland. IV. Further serological investigations of antibodies to group B arboviruses in man and animals. Aust. J. Exp. Biol. Med. Sci., 42: 149-164. 